\section{REFERENCES}

Samson J. Chopin. New York: Schirmer Books, 1996

2. Kuzemko JA. Chopin's illnesses. J Royal Soc Med 1994:87:769-72.

3. Marek GR, Gordon-Smith M. Chopin. New York: Harper \& Row, 1978.

4. O'Shea JG. Was Fréderic Chopin's actually cystic fibrosis? Med J Aust 1987:147:586-9.

5. Majka L, Gozdzik, Witt M. Cystic fibrosis-a probable cause of Frédéric Chopin's suffering and death. J App/ Genet 2003:44:77-84.

6. Mckie R. Row over plan to DNA test Chopin's heart. The Observer, 2008. http://www.guardian.co.uk/music/2008/jul/27/classilcalmusicandopera.genetics (accessed 4 Oct 2010).

7. Karenberg A. Chopin's misery and musician's medical biography. Sudhoffs Archiv 2007:91:82-98.

8. Karenberg A. Ein Leben in Dur und Moll. Fryderyk Chopin aus psychiatrischer Sicht. Dtsch Med Wochenschr 2008;133:2679-85.

9. Long ER. A History of the Therapy of Tuberculosis and the Case of Frédéric Chopin. Lawrence: University of Kansas Press, 1956.

10. Kerner D. Grandes músicos. Sus vidas y sus enfermedades. 5th edn. Barcelona: Ediciones Mayo, 2003.

11. Sterpellone L. Pazienti Illustrissimi. Roma: Antonio Delfino Editore, 1985.

12. Ganche E. Souffrances de Frédéric Chopin. Paris: Mercure de France, 1935.

13. Belotti G. Chopin, I'uomo. Sapere 2000 Edizioni. Milan: Sapere 2000 Edizioni, 1974.

14. Gavoty B. Chopin. In: Vergara J, ed. Buenos Aires: J Vergara Ediciones, 1987

15. Zaluski I, Zaluski P. The Scottish Autumn of Frederick Chopin. Edinburgh: John Donald Publishers, 1993.

16. Niecks F. Frederick Chopin as a Man And Musician. 3rd edn. London: Novello and Company, Ltd, 1902

17. Sand G. Histoire de ma vie. Paris: Gallimard, 2004.

18. Eigeldinger JJ. Chopin Pianist and Teacher as Seen by his Pupils. 3rd edn. Cambridge, UK: Cambridge University Press, 1986.

19. Liszt F. Chopin. 4th ed. Madrid: Espasa-Calpe, 1967

20. Szulc T. Chopin in Paris. New York: Scribner, 1998.

21. Asaad G, Shapiro B. Hallucinations: theoretical and clinical overview. Am J Psichiatry 1986;143:1088-97.

22. Manford M, Anderman F. Complex visual hallucinations. Clinical and neurobiological insights. Brain 1998:121:1819-40.
23. Braun CM, Dumont M, Duval J, et al. Brain modules of hallucination: an analysis of multiple patients with brain lesions. J Psychiatry Neurosci 2003;28:432-49.

24. Podoll K, Robinson D. Recurrent lilliputian hallucinations as visual aura symptom in migraine. Cephalalgia 2001;21:990-2.

25. Kunkel RS. Migraine aure withut headache: Benign, but a diagnosis of exclusion. Cleve Clin J Med 2005:72:529-34.

26. Russell MB, Olesen J. A nosographic analysis of the migraine aura in a general population. Brain 1996;116:355-61.

27. Cohen SI, Blau JN. Lifelong migraine aura without headache: change of pattern with upper respiratory infection. J Royal Soc Med 2003;96:504-5.

28. Hedley A. Selected Correspondence of Fryderyk Chopin. London: Heinemann, 1962

29. Opienski H. Chopin's Letters. New York: Dover publications, 1988.

30. Teunisse RJ, Cruysberg JR, Hoefnagels WH, et al. Visual hallucinations in psychologically normal people: Charles Bonnet's syndrome. Lancet 1996;347:794-7.

31. Teunisse RJ, Cruysberg JR, Verbeek AL, et al. The Charles Bonnet's syndrome: A large prospective study in The Netherlands. Br J Psychiatry 1995:166:254-7.

32. Brown GC, Murphy RP. Visual symptoms associated with choroidal neovascularization. Photopsias and the Charles Bonnet's syndrome. Arch Ophtalmol 1992:110:1251-6.

33. Bien CG, Benninger F0, Urbach $\mathrm{H}$, et al. Localizing value of epileptic visual auras. Brain 2000;123:244-53.

34. Vignal JP, Maillard L, McGonical A, et al. The dreamy state: hallucinations of autobiographic memory evoked by temporal lobe stimulations and seizures. Brain 2007; 130:88-99.

35. Sengoku A. The contribution of J.J. Jackson to present-day epileptology. Epilepsia 2002:43(Suppl 9):6-8.

36. Beyenburg S, Mitchell AJ, Schmidt D, et al. Anxiety in patients with epilepsy: A systematic review and suggestions for clinical management. Epilepsy Behaviour 2005; 7:161-71.

37. Cheyne JA. A webpage about sleep paralysis and associated hypnagogic and hypnopompic experiences. http://watarts.uwaterloo.ca/ acheyne/S_P.html (accessed 10 Jul 2006).

38. Risser AH, Powell FC. Lhermitte's peduncular hallucinosis. An historica perspective. 45th Annual Meeting of the American Academy of Neurology, New York Apr 1993.

\title{
Scott A Weinstein
}

Correspondence to Scott A. Weinstein, Women's and Children's Hospital, 72 King William Road, North Adelaide, South Australia 5003, Australia; herptoxmed@msn.co

Competing interests None declared.

Provenance and peer review Not commissioned; not externally peer reviewed.

Published Online First 12 March 2011

J Med Ethics; Medical Humanities 2011;37:8. doi:10.1136/jmh.2011.007286 